\title{
Effect of the Application of the Licence-Master-Doctorat (L.M.D) System on the Professional Competence of Communication among Students Training in Physical Education
}

\author{
Aymen Hawani, Maher Mrayeh, Mohamed Sami Bouzid, Nizar Souissi \\ Higher Institute of Sport and Physical Education, Tunis, Tunisia \\ Email: hawani.aymen@yahoo.com \\ Received 27 October 2015; accepted 25 February 2016; published 29 February 2016 \\ Copyright (C 2016 by authors and Scientific Research Publishing Inc. \\ This work is licensed under the Creative Commons Attribution International License (CC BY). \\ http://creativecommons.org/licenses/by/4.0/

(c) () Open Access

\begin{abstract}
The purpose of this study is to compare the quality of communication competence of ownership both categories of trainee teachers of physical education (EPS) from two different kinds of academic training. A semi-structured interview was conducted with eight volunteers, five school inspectors and teaching supervisors, five experts in monitoring student teachers from the former regime bac +4 and the current regime LMD. The discussion concluded that student trainees of the LMD system didn't demonstrate the skills and strategies necessary for establishing and maintaining an environment conducive to teaching and learning compared to their counterpart of the old regime master $($ bac +4$)$.
\end{abstract}

\section{Keywords}

Communication Competence, Regime LMD, Inspectors, Supervisors, Semi-Structured Interview

\section{Introduction}

The Tunisian university system has recently undergone profound structural changes. In the area of physical education (EPS), the adoption of a new training curriculum for teachers EPS resulted in the substitution of the course degree, which provided four years of training in the curriculum "license-master-doctorate" (LMD) for a period of three years. For the Tunisian Ministry of Higher Education, we had to bring all the academic training 
system with that of European countries. This ministerial direction had among other objectives professionalizing training (Official Journal of the Tunisian Republic (OJTR) of 30/9/2008 No. 79). In this view, most researchers interested in teacher training argue that professional skills are developed in practical areas (Roux-Perez, 2006; Serres, Ria, Adé and Sève, 2006). Among competences was the communication which had an important role on the quality of education and in terms of student learning (Romainville, 2002; Portelance, 2005; Bourdoncle \& Lessard, 2003).

The implementation of the LMD reform has resulted in a decrease in the time spent on initial training and from 3120 hours to 2268 hours for the new LMD system. The number of hours allocated to teaching practice has also considerably decreased from 182 hours to 112 hours. Given the implementation of the LMD system and its impact on teacher education PSE, it is relevant to question the competence of new trainees for communication. In this perspective, the objective of this work was to gather expert perceptions about the impact of the curricular change on the skills.

\section{Justification of the Choice of the Competence of Communication in the Training of Teachers of Physical Education}

The spectrum of the teacher's functions has broadened considerably. The teacher must simultaneously take into account the personal development of students participate in the school community, build relationships with the immediate community and with society at large and the learning process. Actually, much is expected of the teacher (MEQ, 2001).

For some, this mission may seem burdensome and time consuming. It is possible that these teachers feel more stress, they face more difficulties in the exercise of their duties and have less job satisfaction except as indicated (Le Boterf, 2000; Cosnier, 2008).

In addition, multitudes work indicates that the majority of young teachers and teacher as well as candidates' teaching feel very effective face to ensure their teaching duties when entering career or start their internship preparation for professional life (Dejean, 2002; Esquieu, Fotinos, \& Lopes, 2010; Gervais, \& Correea, 2005; Gelin, Rayou, \& Ria, 2007). Among the difficulties present in the trainee or new teachers, there is that of communication.

Communication in action is to establish a relationship with others and to transmit information, knowledge, or emotion. In psychology, communication is seen as a complex system that takes into account everything that $\mu$ happens when individuals interact (Amade-escot, Chantal ,2003).

Among these interactions, the pedagogical relationship is at the heart of the teaching profession and connects individuals (teacher and students), involves the transmission of various information with the ultimate goal remains the acquisition of knowledge by students. These interactions are complex sequences that integrate verbal and nonverbal messages (Colletta, 2004; Boizumault \& Cogérino, 2010).

\section{Method}

\subsection{Study Population}

Four education inspectors (Karim, Naceur Malek and Lydia [pseudonyme]) with a mean age of $39 \pm 1$ years old and four educational supervisors (Raouf, Seif, Nadia and Syrine [pseudonyme]) with a mean age of $46 \pm 1$ years old, experts in monitoring teacher trainees from the old regime bac +4 and the current regime LMD. Interview participants a thorough understanding of the two programs concerned. The choice of participants was based on the recommendations of management of the Higher Institute of Sport and Physical Education in Tunis (ISSEP) and on the suggestion of some trainers that confirm their skills and dedication to training Initial within ISSEP. The interviews were used to collect the perceptions of experts on changes to physical education and sports programs by the LMD reform and their impact on communication skill shown by the trainees during the course of preparation to the professional life.

\subsection{Protocole Expérimental}

To conduct this study, we opted for a mixed methodological approach using qualitative data. First, a semistructured interview was conducted with eight volunteers, four education inspectors (Karim, Naceur Malek and Lydia [pseudonym]) and four educational supervisors (Raouf, Seif, Nadia and Syrine [pseudonym]), experts in 
monitoring teacher trainees from the old regime bac +4 and the current regime LMD. The interviews were used to collect the perceptions of experts on changes to physical education and sports programs by the LMD reform and their impact on the skills shown by students in relation to the classroom communication. Analysis of the interviews consisted first transcribing interviews verbatim and then analyzed using the general inductive analysis procedure (Blais \& Martineau, 2006).

\subsection{Statistical Procedures}

Analysis of the interviews consisted first transcribing interviews verbatim and then analyzed using the general inductive analysis procedure (Blais \& Martineau, 2006).

\section{Results}

The results presented in this study which addresses both the implementation of the LMD system in the university training curricula of ISSEP and student teachers practice the PSE, suggest that the reduction of time spent on the practice generated by the application of the LMD is associated with lower skills to effectively manage the class in student trainees at the end of LMD initial training. Indeed, in addressing the subject of LMD impact on the teaching practice and particularly on communication, a specific experts face to such a decrease in the time devoted to training, particularly in practical pedagogy course, it is Clearly, the time is not enough to build and develop a skill like the professional competence of communication among students.

Another expert stated that:

The current number of hours devoted to practical teaching internship is very low, therefore the student receives a very theoretical training can therefore proceed to the implementation of this theoretical contribution in practice. 56 hours per semester, the LMD system can not form effective teachers, especially as practically there is no question of 56 hours but much less.

\section{Discussion}

The main purpose of this study is to decide on the quality of the property of one of professional skills in teaching physical education between the two types of teachers from two different training regimes.

The teacher trainee lacks the capacity to adapt to what happens in the classroom, to change interventions but generally they resort to repeat several times the explanation of the exercise and then move to another position (Nadia, 2, 1-12). This is affirmed by Durfour et al. (2010) have shown that lack of necessary skills to classroom communication problems due to inadequate interventions from the teacher. And secondly, Ria et al. (2004) say that trainees and beginners have difficulties in considering ways to achieve their educational goals.

The program of the new LMD system is characterized by an insufficient number of hours of training that does not allow the acquisition of skills such as communication skills. Indeed, the trainee teachers could not acquire enough knowledge and teaching skills in such a short time. Therefore, the reduction of time spent on the practice generated by the implementation of the LMD curriculum is the cause of lack of skills to communicate effectively in the classroom. (Karime, 1, 14-17). However, the construction of professional skills is reflected in duplication of theoretical and practical knowledge through experience (Serres et al., 2006).

Trainee teachers LMD system were less intervention from the type of encouragement that their counterparts maitrisards (old regime). In this regard, an effective teacher who refers to the success of all students, encourage them to provide the necessary efforts to ensure that they complement each other in their best skills of the task they have undertaken. While student teachers of the old regime are distinguished teachers laid off by a higher proportion of comments made (Raouf, 2, 39-42).

We can say that the teachers of the old regime have a skill of communication that encourage better student learning than their colleagues fired (LMD) (Karime, Nadia, Raouf).

\section{Conclusion}

We conclude that the student trainees of the LMD system do not demonstrate the skills and strategies necessary for establishing and maintaining an environment conducive to teaching and learning compared to their counterparts from the old regime Master $(\mathrm{bac}+4)$. We can say that the student trainees of the former regime have a 
communication skill that favors better student learning than their colleagues’ licenciés (LMD).

\section{References}

Amade-escot, C. (2003). Teaching Physical Education, State Research. Paris: Editions EPS Review.

Blais, M., \& Martineau, S. (2006). The General Inductive Analysis: Description of an Effort to Make Sense of the Raw Data. Qualitative Research, 26, 1-18.

Boizumault, M., \& Cogérino, G. (2010). The Beliefs of PE Teachers on Verbal and Non-Verbal Communication: Step with Actual Practice? Communication No. 59. Lyon: University Claude Bernard Lyon.

Bourdoncle, R., \& Lessard, C. (2003). What Is an Academic Professional Training? 2. Specific Features: Programs, Methods and Training Methods. French Revue of Pedagogy, No. 142, 131-181.

Colletta, J. M. (2004). Multimodal Speech and Nonverbal Communication: What Educational Implications? The French in the World.

Cosnier, J. (2008). The Gestures of Dialogue, Communication, Status of Knowledge, Editions. Humanities, 119-128

Dejean, J. (2002). The Evaluation of Teaching in French Universities. Paris: Report Prepared at the Request of the High School Assessment Board.

Esquieu, N., Fotinos, G., \& Lopes, A. (2010). Being Professor of EPS in 2009. “Records”, No. 195, MEN, DEPP.

Gelin, D., Rayou, P., \& Ria, L. (2007). Becoming a Teacher. Courses and Training in Paris. Paris: Armand Colin, 128.

Gervais, C., \& Correea, M.-E. (2005). From the Teacher to the Student: Provide Access to His Experience. In C. Gervais, \& L. Portelance (Eds.), The Knowledge at the Heart of the Teaching Profession: Construction Contexts and Sharing Arrangements (pp. 411-426). Sherbrooke: Publishing CRP.

Le Boterf, G. (2000). Building Individual and Collective Skills. Paris: Editions of Organization.

Ministry of Education, Government of Quebec (2001). The Training of Vocational Education. The Guidance, Vocational Skills.

Official Journal of the Tunisian Republic (JORT) (2008). Decree Setting the General Framework of the System of the LMD System Studies. Official Journal of the Tunisian Republic, 79, 3093-3098.

Portelance, L. (2005). Knowledge and Teacher Training Needs Associated with Period of Implementation of a Curriculum Reform. In C. Gervais, \& L. Portelance (Eds.), The Knowledge at the Heart of the Teaching Profession: Construction Contexts and Sharing Arrangements (pp. 105-128). Sherbrooke: CRP Publishing.

Romainville, M. (2002). The Learning Assessment of Students in University Education. Paris: Report Drawn to the Decontrol of the High Council of the Evaluation of the School.

Roux-Perez, T. (2006). Representation of the Teaching Profession and Education in Relation to Students in STAPS: A Professional Construction Identity. STAPS Journal, 73, 57-69. http://dx.doi.org/10.3917/sta.073.69

Serres, G., Ria, L., Adé, D., \& Sève, C. (2006). We Learn to Really Be Involved in Initial Training? The Premises of the Development of Professional Activity in the Dual Training Devices. STAPS Review, 72, 9-20.

http://dx.doi.org/10.3917/sta.072.09 